\title{
Relationship and patronage as determinants to loyalty programme use amongst Indian youth
}

\section{Sapna Rakesh}

\author{
I.T.S Mohanagar, \\ Ghaziabad, Uttar Pradesh, India \\ E-mail: sapna.rakesh@gmail.com
}

\section{Arpita Khare*}

Indian Institute of Management-Rohtak, Haryana, India E-mail: khare.arpita@gmail.com

*Corresponding author

\begin{abstract}
The purpose of this study was to understand the Indian youths' motives for using loyalty programmes of retailers. The research aimed at studying the behaviour of consumers using loyalty programmes. Indian youth of age group 20-28 years was contacted in the retail stores and data was collected through structured questionnaire $(n=213)$. ANOVA was used to test the differences amongst consumer groups in their use of loyalty programmes based upon their response towards relationship with retailers and proximity to the store. The Indian youth is motivated by the relationship they share with retailers and by using the loyalty programmes. The retailers' should make efforts to build relationship with the consumers, as relationship is a major determinant to consumers' patronage and loyalty behaviour.
\end{abstract}

Keywords: loyalty programmes; relationships; patronage; retailing; Indian youth.

Reference to this paper should be made as follows: Rakesh, S. and Khare, A. (2011) 'Relationship and patronage as determinants to loyalty programme use amongst Indian youth', Int. J. Built Environment and Asset Management, Vol. 1, No. 1, pp.41-55.

Biographical notes: Sapna Rakesh is the Director of Management Programmes in the Institute of Technology and Science, Mohanagar, Ghaziabad. She gained her MBA degree from Jivajee University, Gwalior and $\mathrm{PhD}$ from Kurukshetra University in Retailing. Her current areas of research focus on customer relationship management, brand management and retailing. She has published papers in international and national journals.

Arpita Khare is a Faculty in Indian Institute Management-Rohtak, India. She has a MBA degree in Marketing and DPhil in International Management. Her research interests span over consumer behaviour, retailing, services marketing and supply chain management. She has authored quite a few research papers in international and national journals.

Copyright (C) 2011 Inderscience Enterprises Ltd. 


\section{Introduction}

Retailers' attempt to use strategies to maintain relationships with consumers (Sopanen, 1996) and to increase their retention towards the store (Noordhoff et al., 2004; Patterson and Smith, 2003). In the pursuit of the same, loyalty programmes are considered of vital importance (Dowling and Uncles, 1997; Gómez et al., 2006; Palmer et al., 2000; Roehm et al., 2002). The strategic importance of loyalty programme is to enable consumer retention in the profitable segments by providing consumer satisfaction (Bolton et al., 2000; Mauri, 2003).

In spite of retailers' interest in loyalty programmes, increased competition amongst the retailers makes loyalty programmes much contested battles for consumer retention. The success of loyalty programmes encourages consumers to become business builders for the company by buying frequently, paying premium prices and bringing in new consumers (O’Brien and Jones, 1995). Caminal and Matutes (1990) posit that loyalty programmes can increase brand loyalty and build emotional bonds with the consumers (Palmer et al., 2000).

Indian retailing is growing exponentially from unorganised fragmented systems to more organised structured formats. The change in Indian retailing industry can be attributed not only to the liberalisation efforts of the government, but also to the changing demographics and psychographics of the Indian consumers. Availability of global retailers, branded products and promotions has fuelled the consumers' interest for global brands. Retailers' are vying to increase the store footfall and encourage consumers to purchase from the stores. The drive to retain and give more value to consumers is uppermost in the minds of the retailers. Stiff competition, price-conscious consumers and promotional battles make Indian retailing an interesting area of research. The loyalty programmes are gaining momentum in retailing, as they are supposed to increase consumer satisfaction and help in retaining consumers. The service and retail sector has been using loyalty programmes with mixed results (Rakesh and Khare, 2009) as aggressive marketing efforts were recommended for encouraging consumers to use loyalty programmes.

The consumers' use of loyalty programmes of retailer is attributed to several factors. The behaviour and attitude of the consumers is driven by the intensity of promotions, word-of-mouth (WOM) publicity of the loyalty schemes (and do they recommend it to their friends), store patronage and relationship with retailers. The research targeted consumers use loyalty programmes and aimed to decipher the reasons for Indian youths' behaviour towards retail loyalty programmes in India. The loyalty programme usage was segregated under five reasons: patronage to the store, WOM publicity about the schemes, promotional endeavours, reminders about schemes and relationship with the retailer/store.

Earlier research findings on loyalty card usage amongst Indian consumers had shown (Rakesh and Khare, 2009) that relationship with the retailer was an important dimension in instilling confidence amongst consumers to enrol for loyalty programmes. Indian consumers have been used to the mom-and-pop retail formats and adapting to the more organised retail formats would take time. The consumer shares a personal relationship with the local retailers and is comfortable interacting with them. The loyalty programmes of branded retailers may appear to be an encroachment in their privacy. 
The objectives of our research were to understand:

1 if the consumers' behaviour towards loyalty programme of retailers' is affected by the store patronage, WOM publicity of loyalty schemes, promotions about loyalty schemes and relationship with the retailers

2 the gender differences, if any, in the perception towards these dimensions

3 the behavioural differences amongst consumers, if any, with reference to relationship and trust for a store in encouraging consumers to use loyalty programmes of those stores

4 the behavioural differences, if any, with reference to proximity of a store and consumers use loyalty programmes of those stores.

The consumers' behaviour does not always provide an idea about their loyalty for a store. The consumer appearing to be an avid user of loyalty schemes does not necessarily translate into a loyal consumer. Factors such as convenience, inertia, lack of information, disinterest to explore new options and temporal constraints could be their reasons for using a loyalty programme of a retailer. There may be environmental and social factors influencing their purchase behaviour (Ajzen and Fishbein, 1980; Dick and Basu, 1994; Patterson and Smith, 2003; Smith and Swinjard, 1983). According to the framework provided by Oliver (1999), the consumer satisfaction and loyalty follows a four-step structure; cognitive, affective, conative and action. The reasons for consumers' motivation for loyalty programmes thus become an interesting purview of study.

\section{Literature review}

There is a relationship between consumer retention, satisfaction and loyalty towards a store (Orr, 1995). Noordhoff et al. (2004) define a loyalty programme as a supplier's structural effort to increase consumers' attitudinal and behavioural commitment towards the supplier's products. Research suggests that consumers' loyalty programme membership and loyalty are not necessarily related (Flavia'n et al., 2001; Kivetz and Simonson, 2002; Rakesh and Khare, 2009; Roehm et al., 2002; Rosenbaum et al., 2005; Smith et al., 2003). However, the retailers' interest in loyalty programmes stems from their assumption that loyalty programmes are instrumental in increasing sales and profits (Reichheld and Teal, 1996; Woolf, 1996).

There are behavioural and emotional aspects related to consumers' predisposition towards enrolling for loyalty programmes (Dre'ze and Hoch, 1998; Gómez et al., 2006; McGoldrick and Andre, 1997; Noordhoff et al., 2004). For our research purpose, we assumed that consumers' use of loyalty programme was dependent upon the patronage for the store, positive WOM publicity about loyalty schemes, promotions of the loyalty schemes and the relationship consumers had with the retailers. Samuelson and Sandvik (1997) state that consumer loyalty is a resultant of consumers' attitudes and behaviour. The interaction between consumers' emotions, behaviours and attitudes is important for their conceptualisation of loyalty. The loyalty behaviour consists of scope and continuance of consumers' relationship with the retailer (Hallowell, 1996; Rowley, 2000). 


\subsection{Patronage for the store}

Bloemer and Kasper (1995) posit that consumers' repurchase behaviour from a store cannot be a predictor of loyalty and may be a result of inertia to look for better alternatives. The consumers' shopping intentions can be enhanced by building relationships through reciprocity and instilling trust (Gassenheimer et al., 1998; Gwinner et al., 1998). Research posits the importance of trust in improving patronage behaviour (Everard and Galletta, 2005; Halliday, 2003) and true loyalty for a store would lead to consumers recommending the store to others (Bloemer and De Ruyter, 1998). Lindquist (1974-1975) argues that consumers' loyalty towards a store may be dependent upon a number of store factors such as merchandise, service, clientele, physical ambience, past experiences, convenience, facilities, promotions and institutional factors. The consumers' perception about the store image affects their satisfaction with the store (Bloemer and De Ruyter, 1998; May, 1989; Sivadas and Baker-Prewitt, 2000) and patronage intentions (Bloemer and De Ruyter, 1998). Consumers' predisposition towards using loyalty schemes would be dependent upon their patronage behaviour. The loyalty programmes of stores they visit frequently would hold attraction to them. Amongst the entire loyalty scheme offers they get, the consumers would show a predisposition for a store they patronise.

\subsection{WOM publicity}

The personal influence in the form of WOM is more effective in eliciting positive or negative responses than any other form of communication (Derbaix and Vanhamme, 2003). Lam et al. (2004) posit that a satisfied consumer is likely to patronise the store and also recommend it to others. WOM can be considered as an effective tool for promotion (Buttle, 1998; Sweeney et al., 2008) and for influencing consumer behaviour. It helps in reducing risk (Settle and Alreck, 1989) through social interactions. Consumers pay more attention to WOM because they are customised according to their needs (Silverman, 2001) and are more credible (Herr et al., 1991). In creating favourable attitudes towards loyalty schemes, WOM can play a critical role. The social interactions amongst consumers can enable building confidence over the store's loyalty programme strategies and encourage use of the programmes. Research considers WOM communications as a strategic form of communication that leads building a long-term relationship with consumers (Fornell and Wernerfelt, 1987; Reichheld and Sasser, 1990; Rust et al., 1995; Swanson and Davis, 2003). The satisfied consumers recommend the loyalty schemes to their friends and acquaintances. The effectiveness of loyalty programme gets enhanced through referrals from loyalty programme users.

\subsection{Promotions}

Promotional activities not only differentiate retailers, but are an essential part of marketing them to gain desired response of visits (Roy, 1994). While serving to differentiate the retail stores from one another, promotions should be assessed in light of their intended outcome (Levy and Weitz, 2001). To retain consumers, loyalty programmes have been recognised as a marketing strategy (Srivastava et al., 1998) and are understood as promotional devices used by retailers for consumer retention. Rowley (2007) states that while designing the loyalty programmes, it is important to consider 
the financial benefits and the attitudinal change the loyalty scheme is likely to bring to the consumers. A very high percentage of the consumers who subscribe to a loyalty card are not in fact card-loyal. The more cardholders use promotional inducements, the higher the likelihood that they remain loyal to the card (Mauri, 2003). To stand the best chance of success in tough market, programmes must enhance the overall value of the product or store and motivate loyal buyers to make or upgrade their purchase (Dowling and Uncles, 1997). Promotion plays a key role in attracting consumers to the stores and motivating them to purchase the product.

\subsection{Relationship}

Consumer loyalty is more likely to be gained when the consumer is won over by both a rational argument, such as lowest price or highest quality and an emotional bond (Cuthbertson and Laine, 2004). Short-term transaction-based selling is rapidly being replaced by the relationship-based selling (Bauer et al., 2002). The objective of loyalty programmes is to build a long-term relationship with the consumers and design strategies which would enable a consumer-centric approach (Gable et al., 2008). For ensuring the success of loyalty programmes, it is imperative to establish and nurture the relationship with consumers (Compton, 2005; Topol and Chiagouris, 2005). Consumers' relationship with the retailer would encourage them to use the loyalty programmes. They would feel an emotional bond towards the retailer, and research states the importance of relationship building strategy for loyalty and consumer retention (Bellizzi and Bristol, 2004; Dowling and Uncles, 1997; Gable et al., 2008; Mattila, 2001; Morais et al., 2004; Ross et al., 2005; Yi and Jeon, 2003). Gable et al. (2008) in their research suggest that building relationship with consumers is vital for the success of loyalty programmes. The retailer should give special attention towards understanding the consumers and have a desire to fulfil consumers' expectation (Parasuraman et al., 1988). Griffin (2004) posits that loyalty is build through a series of consumer and retailer interactions and takes time to establish. The retailers' efforts to build a close relationship with consumer would involve consumer orientation than merely focusing on revenue (Conlon, 1996; Gable et al., 2008).

Social interaction with the consumers' can help organisations' build relationships with them and enable them to understand their needs better. Newell (2002) suggests that consumers' seek to develop relationship only with retailers they trust. They prefer to conduct their transactions with retailers' whom they consider reliable, who understands their needs and is able to remember them (Gable et al., 2008; Macintosh and Lockshin, 1997). Social interaction and relationships play a significant role in instilling confidence and loyalty for the retailer (Arnould and Price, 2000; Cova, 1997; McAlexander et al., 2002; Muniz and O'Guinn, 2001).

Relationship with the retailers increases the switching costs for the consumers (Meyer-Waarden, 2002), and consumers participating in a loyalty programme show a greater behavioural loyalty than those not participating in the programme (Ayala and Neslin, 2004; Benavent et al., 2000; Gómez et al., 2006), and they prefer not to look for new retailers (Kim etal., 2001). The trust in the retailer would strengthen the predisposition to use the loyalty programme. 


\section{Methodology}

\subsection{Instrument design}

For designing the questionnaire for measuring consumers' attitudinal and behavioural constructs for loyalty programmes, a thorough analysis on loyalty programme literature was conducted. For drawing the research questions, we conducted a review of researches undertaken in the area which may be considered for defining the constructs to be used for the survey. Initial constructs were drawn after a personal interviews conducted with 20 young consumers enrolled for loyalty programmes. The basic objective herein was to identify constructs considered relevant by consumers while selecting loyalty programmes of retailers. The total number of items in the first phase of questionnaire construction comprised of 32 items. To check the appropriateness of the questionnaire in data collection, we conducted a pilot test on 50 respondents. Out of the 32 items, only 23 items were finally retained. The other nine items were removed, as they were considered ambiguous, repetitive and confusing by the respondents. The total constructs comprised of seven for store patronage behaviour, four constructs for WOM, five for promotions and four constructs for relationship attribute. There were additional two constructs to understand the preference of consumer to use loyalty programme of a nearby store and to a store with which they had a relationship.

\subsection{Data collection}

The sample comprised of the youth population enrolled for loyalty programmes. The age of the respondents ranged between 20 and 28 years. The objective of the research was to understand the effect of patronage to store, WOM, promotions and relationship dimensions related to consumers' use of retail loyalty programmes. The youth in India constitutes a large market segment and understanding their behaviour towards use of loyalty programmes would enable retailers in appropriately marketing their loyalty programmes. The respondents were asked to fill in a structured questionnaire by indicating their agreement on a five-point Likert-type scale (1 - strongly disagree, 5 strongly agree). As most Indians are conversant with English, the questionnaire was administered in English. The final questionnaire was administered on a sample of 250 Indian youth. However, due to sampling errors, some questionnaires had to be eliminated from the final analysis, and a sample of 213 was used for final analysis.

The reliability testing of the questionnaire was done to understand whether the scale could be used for further research purpose. Chronbach's (1951) coefficient alpha measures the extent to which the scale items cohere with each other. We ascertained the reliability of the items by computing the Chronbach alpha, and the score for the 23 constructs was 0.831 . The reliability coefficients of 0.70 or more are considered as a criterion for an internally consistent scale constructs; however, the use of a minimum alpha value of 0.60 is also considered appropriate for initial research instrument validation (Nunnally, 1978). 


\section{Results and discussion}

To analyse the consumers' behaviour towards loyalty programmes, we divided the respondents into five segments based on their preference for enrolling for loyalty programmes of stores with which they had a relationship (based upon their responses). Similarly, they were divided into five segments based on their preference for enrolling for loyalty programmes of stores which were close to their residence (according to their responses).

To understand the relationship between the four aspects determining consumers' predisposition to use loyalty programmes, correlation test was run (Table 1).

The correlation result supports the assumption that for use of a loyalty programme, all the four attributes of store patronage behaviour, WOM referrals, promotions of the loyalty schemes and relationship with the retailers/store are closely related. The Pearson correlation for patronage with WOM $(r=0.448)$, promotion $(r=0.471)$ and relationship $(r=0.475)$ was significant at 0.01 levels $(p=0.000$ for each of the attributes). Similarly for WOM with promotion, $r=0.584(p=0.000)$ and with relationship, $r=0.625$ $(p=0.000)$ which is again significant at 0.01 levels. Promotion with relationship attribute showed a strong positive correlation with Pearson correlation being 0.634 , which was significant at 0.01 levels.

The use of loyalty programmes by consumers, the store patronage (how often they visit and purchase from the store), satisfaction towards loyalty schemes would imply positive WOM, promotions about the programme would act as constant reminders, and it would foster a relationship with the retailer. Both the attitudinal and the behavioural dimensions are significant in loyalty programme use. The Indian youths' preference to use the loyalty programme of a store is affected by the frequency of their visits, positive referrals, the attractive promotional offers and the social interaction. Our research supports earlier research which consumers' loyalty would be governed by store patronage (Halliday, 2003; Everard and Galletta, 2005), positive WOM (Derbaix and Vanhamme, 2003; Lam et al., 2004; Silverman, 2001; Sweeney et al., 2008), promotions (Mauri, 2003; Rowley, 2007) and social relationships (Arnould and Price, 2000; Cova, 1997; McAlexander et al., 2002; Muniz and O'Guinn, 2001). The consumers are bombarded with attractive offers from different retailers. The consumers receive offers through telephone, their mobile phones and e-mails to enrol for loyalty programmes. They use the programme for the monetary rebates and discounts. To differentiate the loyalty programmes, retailers must employ all the four facets and combine the monetary aspects to bring about a behavioural change in the consumers. If the loyalty programmes are targeted without combining the relationship, promotions, WOM and patronage aspects, the permanent change in consumer behaviour would not be achieved.

ANOVA test was run to understand if any differences existed between men and women in their behaviour towards loyalty programmes (Table 2). 
Table 1 Correlation between the loyalty programmes attributes

\begin{tabular}{llcccc}
\hline & & Patronage & WOM & Promotion & Relationship \\
\hline Patronage & Pearson correlation & 1 & $0.448^{* *}$ & $0.471^{* *}$ & $0.475^{* *}$ \\
& Significance (two-tailed) & & 0.000 & 0.000 & 0.000 \\
& $N$ & 213 & 213 & 213 & 213 \\
\multirow{5}{*}{ WOM } & Pearson correlation & $0.448^{* *}$ & 1 & $0.584^{* *}$ & $0.625^{* *}$ \\
& Significance (two-tailed) & 0.000 & & 0.000 & 0.000 \\
& $N$ & 213 & 213 & 213 & 213 \\
\multirow{5}{*}{ Promotion } & Pearson correlation & $0.471^{* *}$ & $0.584^{* *}$ & 1 & $0.634^{* *}$ \\
& Significance (two-tailed) & 0.000 & 0.000 & & 0.000 \\
& $N$ & 213 & 213 & 213 & 213 \\
& Relationship & $0.475^{* *}$ & $0.625^{* *}$ & $0.634^{* *}$ & 1 \\
& Pearson correlation & 0.000 & 0.000 & 0.000 & \\
& Significance (two-tailed) & 213 & 213 & 213 & 213 \\
\hline
\end{tabular}

**Significant at 0.01 level.

Table 2 ANOVA analysis results for gender and loyalty programmes

\begin{tabular}{llrrrrc}
\hline & & Sum of squares & $d f$ & Mean square & $F$ & Significance \\
\hline Store & Between groups & 0.659 & 1 & 0.659 & 0.042 & 0.837 \\
patronage & Within groups & $3,286.337$ & 211 & 15.575 & & \\
& Total & $3,286.995$ & 212 & & & \\
\multirow{5}{*}{ WOM } & Between groups & 43.589 & 1 & 43.589 & 6.055 & $0.015^{*}$ \\
& Within groups & $1,518.900$ & 211 & 7.199 & & \\
& Total & $1,562.488$ & 212 & & & \\
\multirow{5}{*}{ Promotion } & Between groups & 15.597 & 1 & 15.597 & 1.137 & 0.287 \\
& Within groups & $2,894.131$ & 211 & 13.716 & & \\
& Total & $2,909.728$ & 212 & & & \\
Relationship & Between groups & 41.134 & 1 & 41.134 & 4.357 & $0.038^{*}$ \\
& Within groups & $1,992.200$ & 211 & 9.442 & & \\
& Total & $2,033.333$ & 212 & & & \\
\hline
\end{tabular}

*Significant at 0.05 level.

The ANOVA results for gender indicate that there exists a difference within the males and females regarding the behavioural attribute of relationship and attitudinal attribute of WOM of loyalty programmes. The results imply that use of loyalty programmes significantly varies amongst males and females on the WOM and relationship attributes. The WOM publicity and relationship with the retailer are instrumental, affecting women and men in the use of loyalty programmes. The satisfied consumers are likely to recommend loyalty programmes of the retailers to their friends. The use of loyalty programmes would depend upon trust, length of relationship and confidence the consumer feels for the retailer. The results posit that gender differences exist in how loyalty programmes are understood and evaluated. 
To understand if the relationship with the retailers affected the use of loyalty programmes, consumers were categorised into five segments based on their responses related to relationship with retailer and use of loyalty programmes.

The second ANOVA test was conducted to understand if there was any difference between the five consumers segments related to their relationship with retailer behaviour and use of loyalty programmes (Table 3 ). The results clearly indicate that there was a difference amongst groups based on the store patronage behaviour $(F=3.857$ which is significant at 0.01 level). For the rest of the three attributes, there was no difference between the five groups' behaviour and attitude towards loyalty programmes. The interaction with the retailer was dependent upon the frequency of consumers' visit to the store. Patronage to a store affected the consumers' use of loyalty programme. The consumers were not affected by the promotions, WOM and relationship. Patronage was the first step to build a relationship. The use of loyalty programmes, it did not imply that consumers were affected by other three dimensions.

To understand if the proximity to stores affected the use of loyalty programmes, consumers were categorised into five segments based on their proximity to store and loyalty programme use.

The third ANOVA test was run to understand the differences between the five consumers segments based upon their use of loyalty programme of a retailer close to their residence (Table 4). The results indicate that there was a difference amongst groups based on the store patronage behaviour $(F=3.016$ which is significant at 0.05 level). For the rest of the three attributes, there was no difference between the five groups' behaviour and attitude towards loyalty programmes. The loyalty card use is dependent on the store patronage which implies that proximity to a store could lead to frequent repeat purchase. To avail the loyalty programme benefits, the consumer gave importance to a store they patronised.

Table 3 ANOVA for relationship with the retailer and use of loyalty programmes

\begin{tabular}{llcrccc}
\hline & & Sum of squares & $d f$ & Mean square & $F$ & Significance \\
\hline Store & Between groups & 226.966 & 4 & 56.742 & 3.857 & $0.005^{*}$ \\
patronage & Within groups & $3,060.029$ & 208 & 14.712 & & \\
& Total & $3,286.995$ & 212 & & & \\
\multirow{5}{*}{ WOM } & Between groups & 27.652 & 4 & 6.913 & 0.937 & 0.444 \\
& Within groups & $1,534.837$ & 208 & 7.379 & & \\
& Total & $1,562.488$ & 212 & & & \\
\multirow{5}{*}{ Promotion } & Between groups & 87.141 & 4 & 21.785 & 1.605 & 0.174 \\
& Within groups & $2,822.587$ & 208 & 13.570 & & \\
& Total & $2,909.728$ & 212 & & & \\
Relationship & Between groups & 87.197 & 4 & 21.799 & 2.330 & 0.057 \\
& Within groups & $1,946.136$ & 208 & 9.356 & & \\
& Total & $2,033.333$ & 212 & & & \\
\hline
\end{tabular}

*Significant at 0.01 level. 
Table 4 ANOVA for proximity to the store and loyalty programmes

\begin{tabular}{llrrrrr}
\hline & & Sum of squares & $d f$ & Mean square & $F$ & Significance \\
\hline Store & Between groups & 180.197 & 4 & 45.049 & 3.016 & $0.019^{*}$ \\
patronage & Within groups & $3,106.798$ & 208 & 14.937 & & \\
& Total & $3,286.995$ & 212 & & & \\
\multirow{4}{*}{ WOM } & Between groups & 22.839 & 4 & 5.710 & 0.771 & 0.545 \\
& Within groups & $1,539.649$ & 208 & 7.402 & & \\
& Total & $1,562.488$ & 212 & & & \\
\multirow{5}{*}{ Promotion } & Between groups & 87.218 & 4 & 21.805 & 1.607 & 0.174 \\
& Within groups & $2,822.509$ & 208 & 13.570 & & \\
& Total & $2,909.728$ & 212 & & & \\
Relationship & Between groups & 24.222 & 4 & 6.055 & 0.627 & 0.644 \\
& Within groups & $2,009.112$ & 208 & 9.659 & & \\
& Total & $2,033.333$ & 212 & & & \\
\hline
\end{tabular}

*Significant at 0.05 level.

\section{Managerial implications}

The consumers' use of loyalty programmes is more driven by the behavioural dimensions of patronage to a store. The use of loyalty programme thus is attributed to how long the consumers have known the retailers, the trust they feel and the social interaction. These aspects are evident, as consumers' inclination for loyalty programmes in India is determined by store patronage. The loyalty programmes of retailers' the consumers do not frequent are not preferred.

The research found that loyalty programmes are very widely used tools by retailers, who hope that cardholders will keep coming to the stores hoping for point accrual and redemption. The current loyalty programme in the country is more close to the short-term promotional efforts of the firm than towards building base of the loyal consumer for sustenance. Thus, the current structure of the loyalty programmes in the country is not suitable for developing attitudinal loyalty. Loyalty programme may be able to generate behavioural loyalty, as Indians are price-conscious. Consumers may return to the store for getting the privilege of discounts available to loyalty cardholders. Physical proximity of the store has also been found one of the reasons for revisit to the store. In an underpenetrated market, firms will have to develop databases of loyal consumers and use filters to ascertain how many of them are loyal to the store because of physical proximity. It is important to understand that consumers possessing loyalty cards should not be confused as loyal consumers. The long-term sustenance and profitability of the firms would depend upon their ability to differentiate amongst such consumers and develop strategies to build real loyal consumers.

The WOM and repeat purchase would come from base of consumers who patronise store based on attitudinal loyalty. India has a long trade history and historically trade developed on trust though personal relations. Current loyalty programmes are technology based and do not involve individual efforts at the store level to identify and associate with the consumers. The Indians culturally seek pride in knowing the shopkeeper personally 
and passing on the loyalty through generations. New age loyalty programmes are not designed to incorporate this attribute of consumer-retailer relationship. Such relationship measures at institution level may give a huge leverage to the organisations to build attitudinal loyalty. Retailers will have to train employees at store level to interact with consumers at a personal level while integrating it with the marketing objectives of the firm. The social interaction and personalised attention may act as a catalyst to generate store loyalty and consequently use of loyalty programmes. Indian consumers are not technology savvy and do not understand the advantage of buying on coupons or redeeming sales points. It is only in past few years that new age promotional strategies are being used in India. Many consumers feel shy to check at the counter from new people or are not technology savvy to find accrued points on a card and redeem it. Loyalty programmes in the Indian context will have to be customised to integrate the cultural, emotional and social interaction elements of consumer-retailer relationship.

\section{Limitation and future research directions}

This research had been done only on a few retail stores in National Capital Region, and therefore findings can be applied only to a limited population. The researchers could not present data on the success of loyalty programmes of the retail stores to substantiate findings. A research comparing consumer data with company would be of immense use to understand loyalty paradigms. Further research on type of loyalty programmes and efforts, its consequences or potential of acceptance would enable marketers to understand the phenomenon better. The present research targeted the youth and their use of loyalty programmes. Future research could take into consideration of other variables such as different age groups, occupation, education, social class and type of retailers for understanding loyalty programme use in India.

\section{References}

Arnould, E.J. and Price, L. (2000) 'Authenticating acts and authoritative performances', in S. Ratneshwar, D.G. Mick and C. Huffman (Eds.), The Why of Consumption. New York, NY: Routledge, pp.140-163.

Ayala, G. and Neslin, S. (2004) 'The current and future sales impact of a retail frequency retail program', Working Paper, Dartmouth College, Hanover, NH.

Ajzen, I. and Fishbein, M. (1980) Understanding Attitudes and Predicting Social Behaviour. Englewood Cliffs, NJ: Prentice-Hall.

Bauer, H.H., Grether, M. and Leach, M. (2002) 'Building customer relations over the internet', Industrial Marketing Management, Vol. 31, No. 2, pp.155-163.

Bellizzi, J.A. and Bristol, T. (2004) 'An assessment of supermarket loyalty cards in one major US market', Journal of Consumer Marketing, Vol. 21, No. 2, pp.144-154.

Benavent, C., Meyer-Waarden, L. and Crie, D. (2000) 'Analysis of the efficiency of loyalty program as a case study', Proceedings of the Third AFM French-German Conference in Retailing and Distribution in Europe, June, St. Malo, pp.29-30.

Bloemer, J. and De Ruyter, K. (1998) 'On the relationship between store image, store satisfaction, and store loyalty’, European Journal of Marketing, Vol. 32, pp.499-513. 
Bloemer, J. and Kasper, H. (1995) 'The complex relationship between consumer satisfaction and brand loyalty', Journal of Economic Psychology, Vol. 16, pp.311-329.

Bolton, R., Kannan, P.K. and Bramlett, M.D. (2000) 'Implications of loyalty program membership and service experiences for consumer retention and value', Journal of the Academy of Marketing Science, Vol. 28, No. 1, pp.95-108.

Buttle, F.A. (1998) 'Word of mouth: understanding and managing referral marketing', Journal of Strategic Marketing, Vol. 6, pp.241-254.

Caminal, R. and Matutes, C. (1990) 'Endogenous switching cost in a duopoly model', Int. J. Industrial Organization, Vol. 8, pp.353-373.

Chronbach, L.J. (1951) 'Coefficient alpha and the internal structure of tests', Psychometrika, Vol. 16, pp.297-334.

Compton, J. (2005) 'What price loyalty?', Consumer Relationship Management, Vol. 9, No. 3, pp. $14-15$.

Conlon, G. (1996) 'True romance', Sales \& Marketing Management, Vol. 148, No. 5, pp.85-90.

Cova, B. (1997) 'Community and consumption', European Journal of Marketing, Vol. 31, No. 3, pp.297-316.

Cuthbertson, R. and Laine, A. (2004) 'The tole of CRM within retail loyalty marketing', Journal of Targeting, Measurement and Analysis for Marketing, Vol. 12, No. 3, pp.290-304.

Derbaix, C. and Vanhamme, J. (2003) 'Inducing word-of-mouth by eliciting surprise: a pilot investigation', Journal of Economic Psychology, Vol. 24, No. 1, pp.99-116.

Dick, A.S. and Basu, K. (1994) 'Consumer loyalty: toward an integrated conceptual framework', Journal of the Academy of Marketing Science, Vol. 22, No. 2, pp.99-113.

Dowling, G.R. and Uncles, M. (1997) 'Do consumer loyalty programs really work?', Sloan Management Review, Vol. 38, No. 4, pp.71-82. Available at ABI online database on the World Wide Web: http://www-cd.libmassey.ac.nz, Accessed on 21 January 2008.

Dre'ze, X. and Hoch, S. (1998) 'Exploiting the installed base using cross-merchandising and category destination programs', Int. J. Research in Marketing, Vol. 15, pp.459-471.

Everard, A. and Galletta, D.F. (2005) 'How presentation flaws affect perceived site quality, trust, and intention to purchase from an online store', Journal of Management Information Systems, Vol. 22, No. 3, pp.55-95.

Flavia'n, C., Martı'nez, E. and Polo, Y. (2001) 'Loyalty to grocery stores in the Spanish market of the 1990s', Journal of Retailing and Consumer Services, Vol. 8, No. 2, pp.85-93.

Fornell, C. and Wernerfelt, B. (1987) 'Defensive marketing strategy by consumer complaint management: a theoretical analysis', Journal of Marketing Research, Vol. 24, pp.337-346.

Gable, M., Fiorito, S.S. and Topol, M.T. (2008) 'An empirical analysis of the components of retailer consumer loyalty programs', Int. J. Retail and Distribution Management, Vol. 36, No. 1, pp.32-49.

Gassenheimer, J.B., Houston, F.S. and Davis, C.J. (1998) 'The role of economic value, social value and perceptions of fairness in inter-organisational relationship retention decisions', Journal of the Academy of Marketing Science, Vol. 26, No. 4, pp.322-337.

Gómez, B.G., Arranz, A.G. and Cilla'n, J.G. (2006) 'The role of loyalty programs in behavioural and affective loyalty', Journal of Consumer Marketing, Vol. 23, No. 7, pp.387-396.

Griffin, J. (2004) 'Frequently asked questions about consumer loyalty', Available at: www.loyaltysolutions.com/loyalty/LS = www.LoyaltySolutions.com, Accessed on 21 November 2010.

Gwinner, K.P., Gremler, D.D. and Bitner, M.J. (1998) 'Relational benefits in services industries: the consumer's perspective', Journal of the Academy of Marketing Science, Vol. 26, pp.101-114. 
Halliday, S.V. (2003) 'Which trust and when? Conceptualising trust in business relationships based on context and contingency', International Review of Retail, Distribution \& Consumer Research, Vol. 13, pp.405-421.

Hallowell, R. (1996) 'The relationship of consumer satisfaction, consumer loyalty and profitability: an empirical study', Int. J. Service Industries Management, Vol. 7, No. 4, pp.27-42.

Herr, P.M., Kardes, F.R. and Kim, J. (1991) 'Effects of word-of-mouth and product-attribute information on persuasion: an accessibility-diagnosticity perspective', Journal of Consumer Research, Vol. 17, pp.454-462.

Kim, B., Shi, M. and Srinivasan, K. (2001) 'Reward programs and tacit collusion', Marketing Science, Vol. 20, No. 2, pp.99-120.

Kivetz, R. and Simonson, I. (2002) 'Earning the right to indulge: effort as a determinant of consumer preferences toward frequency program rewards', Journal of Marketing Research, Vol. 39, pp.155-170.

Lam, S.Y., Shankar, V., Erramilli, M.K. and Murthy, B. (2004) 'Consumer value, satisfaction, loyalty, and switching costs: an illustration from a business-to-business service context', Journal of the Academy of Marketing Science, Vol. 32, pp.293-311.

Lindquist, J.D. (1974-1975) 'Meaning of image: a survey of empirical and hypothetical evidence', Journal of Retailing, Vol. 50, Winter, pp.29-38.

Levy, M. and Weitz, B.A. (2001) Retailing Management (4th ed.). New York, NY: McGraw hill/Irwin.

Macintosh, L. and Lockshin, G. (1997) 'Retail relationships and store loyalty a multi-level perspective', Int. J. Research in Marketing, Vol. 14, No. 5, pp.487-497.

Mattila, A.S. (2001) 'Emotional bonding and restaurant loyalty', Cornell Hotel and Restaurant Administration Quarterly, Vol. 42, No. 6, pp.73-79.

Mauri, C. (2003) 'Card loyalty: a new emerging issue in grocery retailing', Journal of Retailing and Consumer Services, Vol. 10, No. 1, pp.13-25.

May, E. (1989) ‘A retail odyssey', Journal of Marketing, Vol. 65, No. 3, pp.356-367.

McAlexander, J.A., Schouten, J.W. and Koenig, H.F. (2002) 'Building brand community', Journal of Marketing, Vol. 66, No. 1, pp.38-54.

McGoldrick, P. and Andre, E. (1997) 'Consumer misbehaviour: promiscuity or loyalty in grocery shopping', Journal of Retailing and Consumer Services, Vol. 4, No. 2, pp.73-81.

Meyer-Waarden, L. (2002) 'Les sources d'efficacite' des programmes de fidelisation-Une etude empirique sur la base d'un panel single source', Doctoral Thesis, Universite' de Pau et Pays de l'Adour-IAE, Pau.

Morais, D.B., Dorsch, M.J. and Backman, S.J. (2004) 'Can tourism providers buy their consumers' loyalty? Examining the influence of consumer-provider investments on loyalty', Journal of Travel Research, Vol. 42, pp.235-243.

Muniz Jr, A.M. and O’Guinn, T.C. (2001) 'Brand community', Journal of Consumer Research, Vol. 27, No. 4, pp.412-432.

Newell, F. (2002) Loyalty.com: Consumer Relationship Management in the New Era of Internet Marketing. New York, NY: McGraw-Hill, p.39.

Noordhoff, C., Pauwells, P. and Odekerken-Schroder, G. (2004) 'The effect of consumer card programs: a comparative study in Singapore and The Netherlands', Int. J. Service Industry Management, Vol. 15, No. 4, pp.351-364.

Nunnally, J.C. (1978) Psychometric Theory. New York, NY: McGraw-Hill.

O'Brien, L. and Jones, C. (1995) 'Do rewards really create loyalty?', Harvard Business Review, Vol. 73, pp.75-82.

Orr, A. (1995) 'Consumers for life', Zip/Target Marketing, Vol. 18, No. 3, pp.20-21. Available at ABI online database on the World Wide Web: http://www-cdlib.massey.ac.nz, Accessed on 23 January 2008. 
Oliver, R.L. (1999) 'Whence consumer loyalty?', Journal of Marketing, Vol. 63, pp.33-44.

Palmer, A., McMahon-Beattie, U. and Beggs, R. (2000) 'Influences on loyalty programme effectiveness: a conceptual framework and case study investigation', Journal of Strategic Marketing, Vol. 8, No. 1, pp.47-66.

Parasuraman, A., Zeithaml, V.A. and Berry, L.L. (1988) 'SERVQUAL: a multiple-item scale for measuring consumer perceptions of service quality', Journal of Retailing, Vol. 64, No. 1, pp. $12-40$.

Patterson, P.G. and Smith, T. (2003) 'A cross-cultural study of switching barriers and propensity to stay with service providers', Journal of Retailing, Vol. 79, No. 2, pp.107-120.

Rakesh, S. and Khare, A. (2009) 'The consumers' predisposition towards enrolling for retail loyalty cards: the Indian retail story', Int. J. Electronic Marketing and Retailing, Vol. 2, No. 4, pp.378-396.

Reichheld, F.F. and Sasser Jr, W.E. (1990) 'Zero defections: quality comes to services', Harvard Business Review, Vol. 68, pp.105-111.

Reichheld, F. and Teal, T. (1996) The Loyalty Effect: The Hidden Force Behind Growth, Profits and Lasting Value. Boston, MA: Harvard Business School Press.

Roehm, M.L., Pullins, E.B. and Roehm, H.A. (2002) 'Designing loyalty-building programs for packaged goods brands', Journal of Marketing Research, Vol. 39, No. 3, pp.202-213.

Rosenbaum, M.S., Ostrom, A.L. and Kuntze, R. (2005) 'Loyalty programs and a sense of community', Journal of Services Marketing, Vol. 19, No. 4, pp.222-233.

Ross, I., Gustafsson, A. and Edvardsson, B. (2005) 'The role of consumer clubs in recent telecom relationships', Int. J. Service Industry Management, Vol. 16, No. 5, pp.436-454.

Rowley, J. (2000) 'Loyalty kiosks making loyalty cards work', British Food Journal, Vol. 102, Nos. 5/6, pp.390-397.

Rowley, J. (2007) 'Reconceptualising the strategic role of loyalty schemes', Journal of Consumer Marketing, Vol. 24, No. 6, pp.366-374.

Roy, A. (1994) 'Correlates of mall visit frequency', Journal of Retailing, Vol. 7, No. 2, pp.139-161.

Rust, R.T., Zahorik, A.J. and Keiningham, T.L. (1995) 'Return on quality (ROQ): making service quality financially accountable', Journal of Marketing, Vol. 59, pp.58-70.

Samuelson, B. and Sandvik, K. (1997) 'The concept of consumer loyalty', Proceedings, EMAC Conference, University of Warwick, pp.1122-1140.

Settle, R.B. and Alreck, P.L. (1989) 'Reducing buyers' sense of risk', Marketing Communications, Vol. 14, No. 1, pp.34-40.

Srivastava, R., Shervani, T. and Fahey, F. (1998) 'Marketing based assets and shareholder value: a framework for analysis', Journal of Marketing, Vol. 62, pp.2-18.

Silverman, G. (2001) Secrets of Word-of-Mouth Marketing. New York, NY: AMACOM Books.

Sivadas, E. and Baker-Prewitt, J.L. (2000) 'An examination of the relationship between service quality, consumer satisfaction, and store loyalty', Int. J. Retail and Distribution Management, Vol. 28, pp.73-84.

Smith, A., Sparks, L., Hart, S. and Tzokas, N. (2003) 'Retail loyalty schemes: results from a consumer diary study', Journal of Retailing and Consumer Services, Vol. 10, No. 2, pp.109-119.

Smith, R.E. and Swinjard, W.R. (1983) 'Attitude behaviour consistency: the impact of product trial versus advertising', Journal of Marketing Research, Vol. 20, No. 3, pp.257-267.

Sopanen, S. (1996) Consumer Loyalty Schemes in Retailing across Europe. Oxford: Oxford Institute of Retail Management.

Swanson, S.R. and Davis, J.C. (2003) 'The relationship of differential loci with perceived quality and behavioural intentions', Journal of Services Marketing, Vol. 17, pp.202-219. 
Sweeney, J.C., Soutar, G.N. and Mazzarol, T. (2008) 'Factors influencing word of mouth effectiveness: receiver perspectives', European Journal of Marketing, Vol. 42, Nos. 3/4, pp.344-364.

Topol, M. and Chiagouris, L. (2005) 'To dream the possible dream', Marketing Management, November/December, pp.53-55.

Woolf, B. (1996) Consumer Specific Marketing. New York, NY: Teal Books.

Yi, Y. and Jeon, J. (2003) 'Effects of loyalty programs on value perception, program loyalty, and brand loyalty', Journal of the Academy Science, Vol. 3, pp.229-240. 